\title{
PUBLICATION OF THE KYIV-PECHERSK LAVRA IN THE CONTEXT OF THE CENSORSHIP POLICY OF THE SOVIET GOVERNMENT (1917-1926)
}

\section{ВИДАННЯ КИСВО-ПЕЧЕРСЬКОЇ ЛАВРИ У КОНТЕКСТІ ЦЕНЗУРНОЇ ПОЛТТИКИ РАДЯНСЬКОЇ ВЛАДИ У 1917-1926 РР.}

\section{Natalia Senchenko ${ }^{1}$}

DOI: https://doi.org/10.30525/978-9934-588-53-2-33

Abstract. In the context of the formation of a democratic society, there is a growing need to ensure access to information resources, as modern and those that fell into special funds during the Soviet era. The Orthodox Church suffered irreparable losses during the years of political terror. The revival of religious life in Ukraine will actualize the popularization of church history, culture, traditions, the return of repressed names, and printed publications. In this context, it is of considerable interest to research the censorship policy of the Soviet government in the publishing industry. Analysis of the content, forms, methods, and aftermath of Soviet censorship of printed publications in Ukraine will contribute to a qualitatively new level of knowledge of church history, publishing, museums, archives, will provide an opportunity to return from religious funds banned religious literature as a source of important information. Coverage of censorship policy on church publications will help to reconstruct the degree of its influence on the spiritual component of the Ukrainian people. The subject of scientific research is the process of the formation of political censorship of printed materials in Ukraine, in particular religious works published by the Kyiv-Pechersk Lavra.

The methodological basis of the research was the general provisions of the theory of cognition, based on the principles of historicism, dialectics, systematic, logic. In the process of working on this issue, general scientific methods were used: typology and classification (during the research of the source base), retrospective (to identify the role of censorship at different stages

\footnotetext{
${ }^{1}$ Candidate of Historical Sciences, Senior Research Officer, Leading Researcher, National Kyiv-Pechersk Historical and Cultural Preserve, Ukraine
} 
of its development), modeling (to create a virtual model of censorship control), terminological (to clarify individual definitions), comparative (to identify the features of censorship policy for different types of publications, special attention was paid to the publications of the Kyiv-Pechersk Lavra), analytical (to establish the reasons and consequences terror censorship of publications); special methods - analysis, synthesis, induction, deduction; general historical methods - historical-typological and historical-comparative, which allowed to comprehensively analyze this scientific problem.

The purpose of the dissertation research is to determine the patterns of political censorship of printed publications in Ukraine during this period, in particular works of religious content, published by the Kyiv-Pechersk Lavra. Coverage of the main forms of censorship policy on these works will help to reconstruct the history of Ukraine of the totalitarian era and clarify its impact on the spiritual heritage of the people and identify opportunities for the return of repressed publications to public use.

The results of the research give grounds to claim irreparable loss of the spiritual potential of Ukraine due to the introduction of mechanisms of censorship policy of the Soviet government in 1917-1926. The result of censorship was not only ideological demands on printed publications, but also the creation of special repositories of banned printed materials. Identifying, publishing, and providing free access to repressed publications will provide an opportunity to bring back from oblivion a significant number of valuable works and, as far as possible, to fill the spiritual gap artificially created by apologists for Soviet era communist ideology. The research and publication of problems that have arisen as a result of the influence of censorship policy to ensure the ideological interests of the government become especially relevant in the information society. This is what determines the prospects of scientific research on this topic.

\section{1. Вступ}

У цивілізованому суспільстві кожному громадянину гарантовано право на свободу слова, вільне зберігання, використання, поширення інформації та вираження своїх поглядів. Ці важливі положення стверджуються міжнародними конвенціями та деклараціями.

В умовах формування демократичного суспільства зростає необхідність забезпечення доступу до інформаційних ресурсів, як сучасних 
так і тих, що потрапили до спецфондів у роки радянської влади. Непоправних втрат у роки політичного терору зазнали писемні церковні пам'ятки. Сьогодні відродження релігійного життя в Україні актуалізує популяризацію церковної історії, культури, традицій, поверненню із небуття репресованих імен і писемних пам'яток. У цьому контексті значний інтерес представляє вивчення цензурної політики радянської влади в царині друкованого слова. Аналіз змісту, форм, методів та наслідків діяльності радянської цензури друкованих видань в Україні сприятиме якісно новому рівню знань з історії церкви, видавничої, музейної, архівної справи, надасть можливість повернути із спецфондів заборонену релігійну літературу як джерело важливої інформації в усіх іiі різновидах. Висвітлення цензурної політики щодо церковних видань сприятиме реконструкції іiі впливу на духовну складову українського народу.

Мета наукової розвідки полягає у визначені змісту, форм, методів та наслідків діяльності радянської цензури друкованих видань в Україні протягом зазначеного періоду, зокрема творів релігійного змісту, виданих типографією Києво-Печерської лаври. Висвітлення основних напрямів діяльності цензурних органів сприятиме реконструкції історії України тоталітарної доби, з’ясуванню іï впливу на духовну спадщину народу та виявленню можливостей повернення вилучених видань до загальнодоступного користування.

Завдання дослідження обумовлені його метою: дослідити цензурну політику радянського уряду як засобу ідеологічного впливу; простежити процес формування контрольних органів за друкуванням та розповсюдженням видань; встановити ідеологічне підгрунтя цензури творів друку в Україні в контексті формування радянської політичної системи; з'ясувати наслідки цензурної політики у видавничій галузі на культурне життя суспільства; виявити можливості повернення до загальнодоступного користування заборонених видань.

Методологічну основу дослідження склали загальні положення теорії пізнання, що грунтуються на принципах історизму, діалектики, системності, логічності. У процесі роботи над даною проблематикою застосовувалися загальнонаукові методи: типологізації та класифікації (під час вивчення джерельної бази), ретроспективний (для виявлення ролі цензури на різних етапах іiі розвитку), моделювання (для 
створення віртуальної моделі системи цензурного контролю), термінологічний (для уточнення окремих дефініцій), порівняльний (для виявлення особливостей цензурної політики щодо різних видів друкованої продукції, особливу увагу приділено виданням Києво-Печерської лаври), аналітичний (для встановлення причин та наслідків цензурного терору щодо друкованих видань); спеціальні методи - аналізу, синтезу, індукції, дедукції (для виявлення та дослідження тематики заборонених видань Києво-Печерської лаври,); загальноісторичні методи - історико-типологічний та історико-порівняльний (для всебічного аналізу зазначеної наукової проблеми).

Можливість оприлюднення наукових праць, присвяченим різним аспек-там життя суспільства без догматичного тиску партійної ідеології, реалізувалася після проголошення незалежності України. 3'явились праці, що висвітлювали основні напрями діяльності цензурних органів щодо друкованих видань, у яких розглядалися проблеми суспільно-політичного, релігійного та культурного життя 1920-1930-х рр.

Механізми реалізації масового терору як засобу державного управління, зокрема у видавничій галузі 1920-1930-х рр. в Україні досліджував у своєму науковому доробку С. Білокінь [3, с. 69-76]. Головні завдання Головліту УСРР-УРСР 3 контролю за підготовленими до друку видань вивчав М. Тимошик [29, с. 40-45]. У працях Я. Ісаєвича здійснено історичний екскурс у книговидавничій галузі України [12, с. 319-320; 13, с. 395-419]. Ідеологізація бібліотечної справи у 1920-1930-х рр., негативний вплив бібліотечних «чисток» і вилучення творів на загальний стан бібліотечного фонду України досліджувались у роботі Л. Новохатька [19]. Механізми цензурної політики щодо друкованих видань 1917 - кінця 1930-х рр. висвітлювались у роботах С. Кульчицького, В. Даниленка, Г. Касьянова [7, с. 149-183]. Наукові розвідки Н. Ашаренкової [2, с. 93-101], О. Каракоз [15, с. 29-33; 16, с. 33-37] розкривали проблеми контролю за бібліотечними фондами. Обмеження доступу до інформації та створення спецфондів як результату діяльності цензурних органів торкався у своїх наукових дослідженнях А. Шикман [31, с. 22-31]. Автор, зокрема, наводить імена ініціаторів створення спецфондів, показує тісний зв'язок між органами Головліту та Державного політичного управління (далі - ДПУ). Проблемі повернення із спецфондів заборонених творів 
друку присвятили свої праці В. Іщенко [11, с. 18-19], О. Бригинець, О. Сопронюк [5, с. 4-6]. Бібліотечні спецфонди вивчав В. Очеретянко [21, с. 128-141]. Наслідки бібліотечних чисток 1920-1930-х pp. досліджувались у роботах В. Погребняка [23, с. 8-9]. Історія цензурної політики друкованої продукції в Україні була предметом грунтовного спеціального дослідження О. Федотової [32, с. 1-294]. Однак, особливостей цензурної політики стосовно релігійних видань, зокрема Києво-Печерської лаври, дослідники торкалися побіжно.

\section{2. Нормативно-правова база цензурної політики (1917-1926 рр.)}

Історія знає безліч прикладів заборонних актів, що контролювали доступ до відповідної інформації. Однак різко виділяється тоталітарна система контролю, яка була створена за часів радянської влади. 3 початком будівництва радянської держави нова влада спрямувала зусилля на боротьбу з будь-якими проявами інакомислення. Наслідками цієї політики стало знищення значної кількості друкованих видань, вилучених iз загального та наукового використання кількох поколінь. На жаль цю лакуну уже неможливо заповнити.

Першочерговим об’єктом цензури на предмет відповідності ідеологічним постулатам владного режиму було визначено друковане видання. Особливо жорсткого контролю зазнали видання релігійного змісту та, відповідно, друкована продукція монастирських видавництв, зокрема Києво-Печерської лаври.

3 перших років становлення радянської влади почалися пошуки нових форм цензури та виконавчих органів, які мали виконувати функції контролю творів друку з метою запобігання оприлюднення інформації, несумісної з ідеологією нової влади. Одним із важливих кроків цензурної політики була підготовка та видання відповідних циркулярів, розробка спеціальних інструкцій та положень, що визначали головні напрями цензури друкованих видань. Декрети РНК РСФРР «Про друк» (1917 р.) та «Про революційний трибунал Друку» (1918 р.) сприяли забороні творів так званого «нерадянського» спрямування. Відповідно формувалася й бібліотечна цензура, що вилилась у тотальну націоналізацію, реквізицію та конфіскацію приватних книгозбірень і бібліотек громадських організацій. 3 цією метою було прийнято декрет РНК РСФРР «Про охорону бібліотек та книгосховищ» 
(1918 р.) із додатком про «Про порядок реквізиції бібліотек, книжкових складів та книжок взагалі» (1918 р.) а також постанови Наркомосу УСРР «Про реквізицію бібліотек» (1919 р.).

Усі вищезазначені правові акти були спрямовані на проведення реквізиції та конфіскації книжкових фондів бібліотек і передання їх у розпорядження позашкільного відділу відповідного міського чи повітового відділу народної освіти. Для впровадження бібліотечної цензури на період військових дій була створена Надзвичайна військова цензура. Наркомос УСРР та його бібліотечні секції губернських та повітових відділів позашкільної освіти здійснювали ревізії книжкових фондів бібліотек та масові вилучення «релігійних, монархічних та лубочних» видань.

Рідкісні й цінні видання надсилали до Москви, інші - вміщували до спецфондів новоутворених публічних бібліотек або знищували. Головним критерієм цензурної оцінки була відповідність творів партійній ідеології. 3 часом форми й методи цензурування змінювалися, однак визначальним критерієм залишався принцип ідеологічної одноманітності.

\section{3. Започаткування цензурного органу}

Для нової влади постала нагальною необхідність створення спеціального охоронно-цензорського органу. Із цією метою 6 червня 1922 р. започатковано Головліт СРСР, який здійснював тотальний контроль над друкованими виданнями. Під наглядом Головліту перебували всі книжкові фонди та бібліотечна справа України. 29 серпня 1922 року у структурі Народного комісаріату освіти України було створено український цензурний орган - Центральне управління у справах друку (ЦУСД) на правах підрозділу Головного управління політичної освіти, а 33 січня 1923 року - як окрема структура. У квітні 1925 року ЦУСД реорганізовано на Головне управління в справах літератури та видавництв УСРР (Укрголовліт). Численні адміністративні реформи цензурної діяльності сформували триступеневу систему управління, до якої входили: обліти, райліти або міськліти.

Цензурним відомством складалися зведені покажчики й списки видань, що підлягали вилученню із книготорговельної, бібліотечної, шкільної мереж тощо. Готувалися спеціальні зведені проскрипційні покажчики 3 приміткою «для службового користування», що розсила- 
лися виключно за заздалегідь підготовленим списком. Кожен пронумерований покажчик зберігався із надзвичайними нормами охорони, оскільки його втрата несла за собою сувору відповідальність. Вказані заходи мали забезпечити ідеологічну чистоту друкованої продукції [32, с. 93-110]. Реалізація поставлених завдань здійснювалась за допомогою методу революційного терору (фізичного знищення як опонентів та їх ідеологічної друкованої продукції).

Декретом РНК про пресу (від 27.10.1917 р.) заборонявся випуск періодичних видань, опозиційних ідеологічній політиці партії. У 1918 р. вищим органом цензури став Революційний трибунал друку, основним завданням якого було викриття «злочинів» у видавничій галузі і друкованій продукції. Революційному трибуналу друку дозволялося також і право чинити наступні покарання: 1) штраф; 2) громадський суд; 3) тимчасове або остаточне призупинення видань; 4) конфіскація майна друкарень або органів друку; 5) позбавлення волі; 6) виселення 3 місця проживання; 7) позбавлення політичних прав. Створення Революційний трибунал друку значно активізувало створення спеціалізованого органу цензури [11, с. 18-19].

Одним із перших заходів радянської цензури було проведення націоналізації, реквізиції та конфіскації бібліотек громадських організацій, а також публічних бібліотек, чому сприяли вищезгадані директиви РНК РСФРР. Уся друкована продукція автоматично ставала державною власністю і надходила до бібліотечного відділу Народного комісаріату освіти, який виконував прийняті директиви.

Одночасно продовжувалися пошуки можливостей контролю за інтелектуальною власністю. Наприкінці лютого 1919 р. створено Народний комісаріат радянської пропаганди [26, с. 80-83]. 19 лютого 1919 р. підготовлено проект Народного комісаріату цензури УСРР [32, с. 115], у якому, серед завдань даного відомства, зазначалися наступні: контроль за друкованими виданнями; вилучення з бібліотек і книгосховищ друкованої продукції антиурядового й антиреволюційного спрямування тощо. Планувалося встановити жорстку систему випуску друкованої продукції [9, с. 2]. Усі матеріали, що готувалися до опублікування, підлягали обов'язковому перегляду уповноваженими особами 3 можливістю внесення відповідних коректив. 


\section{4. Контроль видавничої діяльності}

На початку існування радянської влади ставилося питання про тотальний контроль духовного життя суспільства, що стало надалі основним лейтмотивом діяльності інститутів політичної цензури. Постановою НКО РСФРР «Про порядок реєстрації та обліку книг, що видаються у Києві» (1919 р.) передбачався попередній контроль книжкової продукції, що мала друкуватися. Згаданий документ містив наступні положення: 1) Усі видавництва зобов'язані за два тижні до виходу видання у світ подати заяву до відділу постачання Наркомосу із зазначенням кількості його примірників; 2) друкарні інформували про кількість надрукованих книг та їх тираж, 50\% якого обліковувалось відділом постачання та розподілялося за його ордерами за умови, що дане видання не знімалося з обліку; 3) відділ постачання мав право на закупку всього тиражу, або його частини.

У тому ж році вийшла чергова постанова Наркомосу «Про часткове зняття з обліку», якою Київський відділ постачання знімав з обліку наступні категорії літератури: 1) «Євангелія, Біблії, Молитовники; Підручники Закону Божого та богослужбових книг всіх віросповідань ... 2) Підручники з давніх мов - грецької, латинської, церковнослов'янської та всі книги давньоєврейською мовою. Із знятих з обліку книг 3 примірника кожної назви залишали для потреб фундаментальних бібліотек і Наркомосу» [25, с. 24]. Постанови були підписані Народним комісаром освіти (далі - НКО) й визнані обов'язковими до виконання, що доводить спроби установити повний контроль за видавничою галуззю України [32, с. 118].

14 грудня 1920 р. прийнято «Положенням про спеціальні бібліотеки», згідно якого усі видання «не за спеціальністю» вилучалися 3 бібліотек і надходили до Бібліотечного колектора. Восени 1920 р. при НКО розгорнув свою діяльність Головний політико-освітній комітет (далі - Головполітосвіта), одним із напрямів роботи якого стала координація політичної пропаганди ряду відомств. У січні 1921 р. прийнято «Положення про пропагандистський відділ ГПО» (Головне управління в справах політико-просвітницької роботи), якому належало проводити вилучення ворожих і застарілих видань під гаслом пристосування бібліотек для потреб комуністичної освіти. Організована після березневого Пленуму ЦК спеціальна комісія прийняла рішення: 
«Госиздату немедленно снестись с ЦБК относительно изъятия из дальнейшего оборота и из распространения по библиотекам и пр. тех изданий, которые по направлению оказались напечатанными лишь в силу преступной оплошности органов Госиздата» [10, с. 83].

\section{5. Створення спецфондів}

На виконання цього рішення у Центральній книжковій палаті було створено спеціальний фонд друкованих видань, який мав зберігати вилучені твори. Бібліотечні чистки 1920-1921 рр. були спрямовані переважно на перерозподіл уже наявного бібліотечного фонду і стали причиною створення спецфондів у бібліотеках, хоча й не були єдиним джерелом його формування. У 1922 р. напрями роботи спецфондів значно розширились. Так, наприклад, 6 травня Центральним бібліографічним відділом при Всеукраїнському державному видавництві до Центральної книжкової палати було відправлено партію українських книг із метою їх спеціального використання, про що свідчить наступний лист: «Настоящим Н. Б. О. извещает Вас, что им отправлено 26 апреля со станции Харьков на станцию Москва 6 (шесть) тюков, содержащих 5383 экземпляра: образцов произведений печати, вышедших на территории УССР. Указанные образцы посылаются для хранения в Вашем книгохранилище в качестве особого фонда печати УССР. Пользование ими должно быть предоставлено исклю-чительно в помещении книгохранилища для научной работы и справок преи-мущественно научным и политическим работникам, причем эти образцы ни в коем случае не могут быть выдаваемы на дом» [17, с. 20].

У циркулярі, підготовленому Головлітом зазначалося «Товарищи! В настоящее время большое значение приобретает печатное слово, одновременно являющееся могучим средством воздействия на настроение разных групп населения Республики, как в наших руках, так и в руках наших противников... Цензура является для нас орудием противодействия растлевающему влиянию буржуазной идеологии. Главлит (организованный по инициативе ЦК РКП) имеет своей основной задачей осуществить такую цензурную политику, которая в данных условиях является наиболее уместной. Опыт цензурного воздействия выдвигает два основных пути цензурной политики: первый путь - административное и судебное преследование, которое выражается в закрытии 
издательств или отдельных изданий, сокращении тарифа, наложении штрафа и предании суду ответственных лиц. Второй путь - путь умелого идеологического давления, воздействия на редакцию - путём переговоров, вводе подходящих лиц, изъятия наиболее неприемлемых и т. д. Органам Главлита необходимо иметь тщательное наблюдение не только за частными, но и за кооперативными, профсоюзными, ведомственными и прочими издательствами...» [6, с. 146-147].

За Головлітом закріплювалися наступні завдання: 1) попередній перегляд усіх запланованих для опублікування або розповсюдження творів; 2) надання дозволу на опублікування окремих видань; 3) підготовка списків документів, заборонених для продажу [32, с. 122]; 4) видання правил, розпоряджень та інструкцій у справах друку, видавництв, друкарень, бібліотек і книжкових магазинів.

Щодо здійснення попередньої цензури творів друку, слід наголосити на розробці та застосуванні принципово нового механізму для iii реалізації, суть роботи якого полягала в тому, що відхилені під час контролю рукописи підлягали негайному знищенню. На запит одного iз архівних бюро передати на архівне зберігання окремі рукописи 3 поміткою Головліту, він надіслав відповідь: «Гранки й тексти рукописів здачі до Центрархіву не підлягають, їх варто знищувати як секретний матеріал, що втратив своє значення» [32, с. 152]. Факт заборони цензорами будь-якого тексту означав не що інше як остаточну втрату його цінності для людства.

Не допускалися до друку відомості, що не підлягали розголошенню (за спеціально затвердженим переліком) і статті, які мали «ворожий характер» по відношенню до ідеології партії та радянської влади [20, с. 1-10]. Заборонялися й друковані твори, якими здійснювалась «ворожа пропаганда» у розумінні суспільного, релігійного, національного, економічного та інших питань. Цензорам надавалося також право вилучення зі статей «гострих місць», у яких компрометувалася радянська влада й комуністична партія.

\section{6. Вилучення релігійних видань}

У 1922 р. в Україні виникла потреба в упорядкуванні вилучених видань та розробки методики їх зберігання й використання. Розподіл «репресованих» видань мала здійснювати Книжкова палата України. 
Організація ії роботи визначалася постановою РНК від 27 липня «Про організацію Української Книжкової палати УСРР та про забезпечення Головних державних книгосховищ усіма виданнями Республіки». Схемою розподілу обов'язкових примірників, введеною в дію з 1 серпня, фактично був задекларований факт організації в Книжковій палаті спецфонду, який спочатку мав назву «запасний фонд» [24, с. 41]. Укрліт пропонував направляти до Книжкової палати лише ті матеріали, про які, після перегляду списків, приймалося спеціальне рішення. Даною постановою було також започатковано створення спецфонду у Всенародній бібліотеці України (далі - ВБУ), котрій передавався 4-й примірник конфіскованих видань. У звернені від 27 лютого 1923 р. комітет ВБУ просив Політконтроль Державного по-літичного управління (далі - ДПУ) надати бібліотеці по одному примірнику всіх вилучених видань, що зберігалися на складах Києво-Печерської лаври $[18$, с. 5]. Однак дозволу не отримав. У наступному листі комітет знову намагався отримати видання через органи Політконтролю, або Український науковий інститут книгознавства. Результатом вищезазначених клопотань було передання до ВБУ видань Київської духовної академії та інших духовних закладів.

Серед вилучених видань, значна частка (майже половина) припадала на твори релігійного змісту, про що свідчить статистика про кількість вилученої літератури за 1925 р. у м. Вінниця: анархістської-3\%, есерівської меншовицької - 8\%, релігійної богословської - 45\%, учбової - $20 \%$, белетристики - 7\%, дитячої - 6\%, кадетської монархічної 8\%, у тому числі 10 пудів 27 фунтів петлюрівської [8, с. 42].

Однак, проблеми з підготовки повних списків заборонених видань продовжувались залишалися актуальними, про що свідчить декрет ВУЦВК від 30 квітня 1925 р., згідно якого обов'язки по складанню списків забороненої, конфіскованої або знищеної літератури знову ж таки покладалися на Українську книжкову палату.

Наступним кроком жорсткої цензури було звернення (від 19 вересня 1924 р.) до всіх бібліотек про необхідність вилучення видань «контрреволюційного та релігійного характеру», а також інструкція НКО (від 21 грудня 1925 р.) «Про порядок перегляду літератури на предмет іiі ідеологічного спрямування та вилучення шкідливої літератури із книгозбірень й читалень, книгарень та кіосків ринку». Згідно даної дирек- 
тиви розпочалося активна робота із вилучення усіх «ворожих» видань i розробки методики їх заборони. Зазначалися книги, що підлягали негайному вилученню, серед яких першими у списку значилися: релігійні твори, що містили елементи релігійної агітації та пропаганди, наприклад, релігійні трактати, описи життя святих, книги з історії церкви, монастирів то-що; книги з історії філософії, релігійно-догматичні й богословські-філософські твори (серед них - Володимира Соловйова, Василія Великого, Іоанна Златоуста та ін.) залишалися в одному примірнику; видання з питань філософії, психології, етики, присвячені окультним наукам, спіритизму, теософії тощо [26, с. 133]; література царського періоду, видана різними урядовими установами, церковними й чорносотенними патріотичними організаціями, такими як партія «монархістів», «октябристів», «Союз русского народа», «Союз Михаїла Архангела»; друкарнями Свято-Троїцької та Києво-Печерської лавр; видання Синоду та ін.; матеріали «шовіністичного характеру», що побачили світ за часів Центральної Ради, Гетьманщини та інших «контрреволюційних урядів»; білоемігрантська література; ...застарілі педагогічні видання, що пропагували релігійні погляди, монархізм, націоналізм тощо; ...наукові твори, в яких розглядалися питання науки та релігії, критично висвітлювалися засади дарвінізму та матеріалізму; видані за царських часів історичні матеріали, що підносили монархізм, церкву, царську династію... [32, с. 133].

В інструкції вказувалось, що значна кількість зазначеної літератури знаходилась у фондах міських бібліотек, в районних і сільських книгозбірнях. Директивою чітко встановлювався термін (до 1 грудня 1926 р.), протягом якого необхідно було вилучити дані матеріали. Варто зазначити, що уперше відкрито рекомендувалося використовувати списки заборонених видань, складених Головлітом та Укрлітом, під час проведення відповідних рейдів. Окрім створених спецфондів функції спецзберігання покладалися також і на наукові бібліотеки.

\section{7. Вилученні видання Кисво-Печерської лаври}

Друкарня Києво-Печерської лаври була заснована у 1615 р. Навколо неї групувалися видатні громадські діячі, літератори, учені, художники. Серед них - Слисей Плетенецький, Памва Беринда, Захарія Копистенський, Іов Борецький, Петро Могила, Опанас Кальнофой- 
ський, Інокентій Гізель і багато інших. Найраніше видання Лаври, що дійшло до нас - «Часослов» (1616 р.) У лаврській друкарні побачили світ розкішно оправлені і прикрашені гравюрами «Житія» святих, Свангелія, Акафісти, Псалтирі, букварі, календарі, твори з історії церкви, зокрема «Тератургіма» (1638р.) Опанаса Кальнофойського, «Требник» (1645р.) Петра Могили, «Патерик Печерський» (1661р.), «Синопсис» (1674р.) Інокентія Гізеля.

До середини XVIII ст. лаврська друкарня практично не мала конкурентів. Завдяки роботі таких граверів як Л. Тарасевич, Д. Галяховський, А. Козачковський та інших, гравюра досягла високого професійного рівня, стала широко відомим жанром мистецтва. Видання Києво-Печерської друкарні користувалися популярністю не лише завдяки поліграфії і ілюстраціям, але й глибокого духовного змісту. У 1627 р. публікується «Лексикон словеноруський» лаврського ієромонаха Памви Беринди - перший тлумачний словник церковнослов'янської мови. У 1635 р. виходить «Патерикон» - перше друковане видання древнього «Києво-Печерського Патерика».

Патерик, складений у XIV-XV ст. з творів XI-XIII ст. про подвижників Лаври домонгольского часу, став першою на Русі вітчизняною книгою такого жанру, що прийшов до нас із Візантії. У 1638 р. друкується «Тератургіма» - книга лаврського ченця Опанаса Кальнофойського польською мовою з розповідями про дивовижні події, що відбувалися біля печерських святинь. У 1689-1705 рр. Лавра видала перший у світі друкований звід «Житій» святих Православної церкви, який склав святитель Дмитро Ростовський (Туптало †1709) - син козацького сотника, вихованець Київської духовної академії, постриженик Свято-Кирилівської обителі у Києві. Роботу над зводом подвижник почав у Лаврі, для чого і був запрошений. У 1741-1742 pp. в друкарні працював рясофорний чернець Платон Величковський, майбутній великий подвижник Паїсій.

Цей короткий екскурс в історію подано з метою окреслити хоча б приблизні контури того духовного скарбу, який зуміла зберегти і опублікувати Києво-Печерська лавра. Протягом усього наступного періоду свого існування друкарнею монастиря видано велику кількість безцінних творів, які згодом стали писемними церковними пам'ятками. Однак за часів радянської влади друкована продукція Києво-Печерської лаври 
потрапила під заборону. Значна частина видань, що до сьогодні знаходяться як у спецфонді Книжкової палати так і інших спецфондах України, залишаються невідомими як для наукової спільноти так і пересічному читачеві. Науковцям належить здійснити значну пошукову та наукову роботу: виявити, дослідити та оприлюднити заборонені твори, серед яких є чимало надзвичайно рідкісних та цінних видань.

Одним із останніх опублікованих видань Києво-Печерської лаври - «Венок на могилу высокопреосвященнаго митрополита Владиміра (†25 февраля 1918 г.)» під редакцією заслуженого професора протоієрея Феодора Титова - це документальні свідчення життєвого шляху та духовного подвигу митрополита Київського і Галицького Володимира (Василя Никифоровича Богоявленського). Книга насичена фактами, що висвітлюють і документально підтверджують події суспільного, політичного, релігійного життя як Києва так і України 1917 - початку 1918 pp. В останні дні життя митрополиту Володимиру довелось перенести надзвичайно багато неприємностей та образ. Особливо важко переживав митрополит збройні конфлікти українських і більшовицьких військ. Під свист куль та гуркіт канонади він продовжував служити в Успенському соборі обителі.

Військові дії спричинили значні руйнування у Києво-Печерській лаврі. 15 січня 1918 р. на територію обителі потрапив перший артилерійський снаряд. 16-23 січня монастир продовжували обстрілювати. Особливо великих втрат зазнали: Успенський собор - пам'ятка церковного зодчества XI ст.; лаврська дзвіниця (XVIII ст.), друкарня (XVII ст.) та інші об'єкти. 23 січня більшовики захопили Києво-Печерську Лавру. У монастирі розпочалися дикі акти варварства, насилля, пограбування, кощунства над святинями, свавілля під час богослужінь, знущання над ченцями, страти військових. У ніч з 25 на 26 січня митрополита Володимира озброєні солдати вивели за територію монастиря i по-звірячому вбили: стріляючи розривними кулями і проколюючи тіло священномученика гострою зброєю [4, с. 5-57].

Після знайомства із хронологією вбивства митрополита стає зрозуміло, чому дане видання потрапило під заборону: неприваблива правда про більшовицький терор не мала права на існування у часи їхнього перебування при владі. Незаперечні свідчення більшовицького насильства мали бути стерті з пам'яті поколінь. Однак, історія розпо- 
рядилася по-іншому. І достовірна інформація має стати доступною для широкого загалу.

28 червня - 11 липня 1918 р. у Києві відбувся Всеукраїнський Собор Православної церкви з метою обговорення церковних справ у світлі революційних подій. Собор прийняв звернення до народу України, у якому дана богословська оцінка останніх подій з позиції релігійного вчення, проведено паралелі відповідності тогочасного стану суспільства ідеалу духовної особистості. Собор осудив жорстоке вбивство митрополита Володимира (Богоявленського), який вмираючи, просив Бога простити своїх вбивць. Матеріали Собору, видані окремою збіркою, також були «репресовані» цензурою і вміщені до спецфонду Книжкової палати України [14, с. 1-23].

Інший пласт забороненої літератури становлять видання з історії Православної церкви, становлення унії, боротьби українського народу за вільне сповідування своєї віри тощо. Репрезентативним у цьому контексті є «репресоване» більшовицькою владою видання Києво-Печерської лаври «Польша и Москва в отношеніи к православной вере в Юго-Западной Руси». Автор даного дослідження Д. Скринченко висвітлює становище православного населення України після прийняття унії 1596 р., проводить паралелі із відповідними ярликами татарських ханів, показує можливості реалізації суспільних прав і релігійних свобод населення; висвітлює роль православних братств у відстоюванні прав і свобод українського народу; розкриває сутність розпоряджень пануючої влади по відношенню до православної віри тощо. Насичена історичними фактами книга показує роль церкви у житті українського народу, що, вочевидь, не могло сподобатися радянській цензурі. Не вдаючись до подробиць, не оцінюючи історичну цінність видання, репресивна машина більшовизму знищувала усе, що не вкладалося у їі ідеологічні рамки [27, с. 1-34].

Наступну групу друкованих видань Києво-Печерської лаври, вилучених і вміщених до фонду забороненої літератури Книжкової палати України становлять видання відомих церковних діячів, що стосувались аналізу суспільної, політичної, економічної, культурної, релігійної ситуації в Україні зазначеного періоду. У цьому контексті виділяється зібрання творів митрополита Антонія (Храповицького) (1918р.). Автор розкриває причини важкого економічного, політичного, культурного 
стану України цього періоду, вказує шляхи виходу із глибокої духовної кризи - як основи відродження усього суспільного життя країни. Переконливо аналізує причини і наслідки варварських актів вбивств, насилля, пограбувань: «Что же вышло от этой злой науки народныхъ развратителей? ...научили народъ обогащаться чрезъ забастовки и грабежи, а страна разорилась, и все сидятъ безъ хлеба, без одежды и обуви; понабрали себе денег, а деньги стали ничего не стоить и никому не нужны. Научили народ не стыдиться греха и упиваться житейскими наслаждениями, а все ходятъ с унылыми лицами, подавленные стыдом и безплодною тоскою, а то и отчаяніемъ. Настала тяжкая пора... эти скорби не от внешних враговъ, а от нашего собственнаго безумія... Нужно оплакать утерянную любовь къ добродетели, къ святым подвигамъ воздержанія и молитвы...» [1, с. 6-7]. Чому ці твори потрапили до спец-фонду, адже моральне удосконалення особистості не суперечило планам будівників нової держави? Головна причина - це релігійна складова - несумісна із атеїстичним спрямуванням стратегії розбудови держави та з принципово новою ідеологією.

Інший пласт заборонених видань цього періоду присвячено висвітленню боротьби з християнством у різні історичні періоди його існування. Репрезентативною у цьому контексті $є$ праця священника Миколи Успенського «О поругании святых мощей» (1919р.), у якій подано історичний екскурс боротьби з християнством. Автор доводить, що новій владі, озброєній атеїстичною ідеологією, недостатньо було пограбувати матеріальні багатства України, вона намагалася знищити душу народу - християнську віру не гребуючи самими огидними методами вандалізму і святотатства. Катування священства і віруючих набули таких звірячих форм, що перевершили древніх гонителів християн. У роботі автор проводить екскурс в історію шанування святих мощей, розкриває сутність їх феномену. Доводить, що нетління мощей залежить не від особливостей навколишнього середовища, де вони перебувають, а від святості життя подвижника. У Києво-Печерській лаврі знаходяться мощі святих, які довгий час перебували у місцях 3 різною температурою і вологістю повітря, однак залишились неушкодженими. Так, преподобний Євстратій Печерський, взятий у полон половцями і убитий на Пасху (1096р.), довгий час знаходився у воді, однак його тіло залишилось нетлінним і сьогодні почиває у Антоні- 
євих печерах Києво-Печерської лаври. Радянська влада здійснювала дикі акти вандалізму і святотатства над святими мощами, намагаючись таким чином знищити віру народу [30, с. 2-15].

До заборонених видань Києво-Печерської лаври потрапила «Краткая льтопись перваго Всеукраинскаго церковнаго Собора и его важнъйшие постановленія въ январђ и іюнъ 1918 г. (с приложеніемъ переписки о высшемъ управленіи православной церкви на Украине)». На п’ятому засіданні, що відбулося 18 червня - 1 липня 1918 р., було оголошено пропозицію Н.С. Гроссу: «...выразить от лица собора правительству благодарность за многоразличное благожелательное отношеніе его к православной церкви на Украине и къ церковному собору, но вместе съ темъ отметить въ деклараціи министра исповеданій и въ самыхъ действіяхъ министерства, насколько о нихъ была речь въ деклараціи, мысли и факты, противоречащіе идее свободы церкви и вызывающіе в членахъ собора опасенія за независимость церкви въ будущемъ» [14, с. 6]. Найважливіші рішення Всеукраїнського Церковного собору були зафіксовані у наступних постановах: про звільнення духівництва від особистих повинностей і подаків, а церковно-ружних земель - від поземельних зборів; про охорону майнових інтересів Православної церкви в Україні; про церковний календар; про тимчасове Вище керівництво Православною церквою в Україні; про матеріальне забезпечення українського духівництва; про духовні учбові заклади; про обов'язкове виконання Православною церквою в Україні постанов Священного Собору «Православної Російської Церкви» і Патріарха та ін. Не вдаючись до детального аналізу причин вилучення документів Собору, зазначимо, що на Соборі піднімалось чимало проблем, що і сьогодні є актуальними для України. Досвід їх вирішення актуалізує необхідність повернути разом із іншими і ці видання для широкого доступу громадськості.

За тематичним спрямуванням можна виділити ще одну групу видань, що торкалися діяльності православних братств, товариств та інших релігійних об'єднань. Репрезентативним у цьому контексті є «Статут українського православного братства імені святих Кирила і Мефодія», видане типографією Києво-Печерської лаври у 1918 р. Головним завданням братство визначило «...відбудування ...Церкви... нести в маси світло знання й науки. Братство буде боротися 3 темрявою силою 
ідеї, як незабутньої пам'яті Братства XVI - XVII ст. на Україні, - . . як боролися Кирило-Мефодієвці 1846 року» [28, с. 5]. Відбудова церкви в Україні проголошувалося одним із головних завдань національного відродження України. «Пам’ятаючи заповіді Христові, Брацтво ширити буде ідею згоди, християнської любови та брацтва всіх народів, на Україні сущих, всіх славян і народів світу. Брацтво має: а) видавати книжки, журнали, часописи і т. і.; б) заводити свої бібліотеки, музеї, читальні, книгарні, і т. і. в) впоряджати публічні лекції і відчити, загально-просвітні курси, літературно-музичні вечори, концерти, вистави, і т. і.; г) заводити стипендії, школи, захистки про дітей і дорослих, бюро праці і т. інші просвітні і добродійні заклади; д) оповіщати конкурси і премії за найкращі твори письменства та умілості» [28, с. 5-6]. Однак подібні плани не співпадали із намірами нової радянської влади. Цензурна машина спрацювала досить оперативно, вилучивши і помістивши зазначені матеріали до спецфонду Книжкової палати.

Автор намагався окреслити і дати максимально стислу характеристику лише деяких груп заборонених видань, об'єднаних за тематичним принципом і виданих типографією Києво-Печерської лаври. Ця робота потребує продовження. Репресовані видання чекають глибокого і всебічного наукового вивчення та оприлюднення.

\section{8. Висновки}

Проведене дослідження дає підстави стверджувати, що впровадження цензурної політики призвело до вилучення з відкритого доступу великої кількості цінних видань з різних галузей знань, безповоротно втрачених сьогодні, сформувавши величезну лакуну у культурній спадщині українського народу. Значну частину їх склали релігійні твори, видання з історії церкви, патристики, патрології тощо, про що свідчать незаперечні приклади заборонених видань друкарні Києво-Печерської лаври. Цілеспрямоване знищення творів друку або переміщення їх до спецфондів позбавили кілька поколінь українського народу значного пласту цінних джерел інформації, без якої надзвичайно важко відродити духовне життя суспільства.

Онтологія становлення будь-якої влади свідчить про закономірність включення репресивної машини для забезпечення обраного ідеологічного спрямованості. Цензурна політика радянського уряду зазначе- 
ного періоду не стала винятком, а навпаки, досягла небачених масштабів діяльності: вилучаючи і знищуючи неугодні друковані видання. Результати діяльності інститутів радянської цензури протягом усього періоду іiі існування були досить відчутними: в Україні було створено 28 спецфондів, із яких 10 - знаходилися в Києві.

Перспективи подальших досліджень зазначеної тематики, мають знахо-дитися у площині виявлення можливо ще невідомих форм i методів цензурного терору проти друкованих видань, повернення із забуття та забезпечення вільного доступу до «репресованих» творів релігійної тематики поряд із творами з інших галузей знань. 3 метою відтворення цілісної картини історії Києво-Печерської лаври перед науковцями стоїть завдання повернути із забуття усі їі видання, як свідків багатовікового шляху духовної святині.

У сучасному інформаційному середовищі збереження національної ідентичності та самобутності народу набуває особливої гостроти і можливе лише за умови збереження духовного і культурного надбання попередніх поколінь. А це потребує як подальших розробок необхідної законодавчо-правової бази з реалізації свободи слова так і поверненню із небуття та спецфондів усіх без винятку духовних скарбів України.

\section{Список літератури:}

1. Антоній (Храповицкий), митрополит. Полное собрание сочинений. T. IV. Киев : Киево-Печерская лавра, 1919. С. 6-7.

2. Ашаренкова Н.Г. Вплив цензури на діяльність публічних бібліотек України (20-30 рр. ХХ ст.). Украӥна XX ст.: культура, ідеологія, політика. 36 ст. Вип. 5. Київ, 2001. С. 93-101.

3. Білокінь С. На полицях спецфондів у різні роки. Слово $і$ час. 1990. № 1. С. 69-76.

4. ВЪнок на могилу высокопреосвященнаго митрополита Владиміра / под. ред. Ф. Титова. Київ : Тип. Кіево-Печерской Лавра, 1918. 92 с.

5. Бригинецъ О., СопронюкО. Ланцюгова реакція ... порожнечі? [Про «репресовану» літ.]. Ранок. 1990. № 7. С. 4-6.

6. Горяева Т. М. Политическая цензура в СССР 1917-1991. РОССПЭН, 2002. 400 с. (Сер. «Культура и власть от Сталина Д० Горбачёва. Исследования»). С. 146-147.

7. Даниленко В. М., Касьянов Г. В., Кульчицький С. В. Сталінізм Україні: 20-30-ті роки / В. М. Даниленко ; Ред. С. О. Васильченко. Київ : Либідь, 1991. 344 с.

8. Декрет ВУЦВК від 30 квітня 1925 р. про передання функцій по складанню списків забороненої, конфіскованої або знищеної літератури на Українську книжкову палату. ЦДАВО України. Ф. 166. Оп. 4. Спр. 968. Арк. 42. 
9. Доповідь М. Бойкова голові Тимчасового робітничо-селянського уряду України Х. Раковському про створення Народного комісаріату цензури УСРР (проект) від 19 лютого 1919 р. ЦДАВО України. Ф. 2. Оп. 1. Спр. 467. Арк. 2.

10. Зеленов М. В. Аппарат ЦК ВКП(б) - ВКП(б), цензура и историческая наука в 1920-е годы. Ниж. Новгород, 2000. 540 с.

11. Іщенко В. Що повернено із «спецхранів». Соціалістична культура. 1990. № 8. С. 18-19.

12. Ісаєвич Я. Україна давня і нова: народ, релігія, культура / НАН України. Ін-т українознав. ім. І. Крип’якевича. Львів, 1996. 336 с.

13. Ісаєвич Я. Українське книговидання: витоки, розвиток, проблеми. Львів : Ін-т українознав. ім. І. Крип'якевича НАН України, 2002. 520 с.

14. Краткая летопись Перваго Всеукраинского Церковнаго собора и его важнейшія постановленія въ январе и іюне 1918 г. Київ : Тип. Кіево-Печерской Лавры, 1918. 22 с.

15. Каракоз О. Бібліотечна цензура в Україні в двадцяті роки XX століття. Вісник Книжкової палати. 2004. № 11. С. 29-33.

16. Каракоз О. Витоки бібліотечної цензури на Україні. Вісник Книжкової палати. 2003. № 5. С. 33-37.

17. Лист Центрального бібліографічного відділу при Всеукраїнському державному видавництві від 6 травня 1922 р. про передання Центральній книжковій палаті партії українських книг з метою їх спеціального використання. Наук. арх. Кн. палати України. Ф. 5131. Спр. 133. Арк. 20.

18. Лист Комітету ВБУ до Політконтролю ДПУ від 27 лютого 1923 р. про надання бібліотеці одного примірника видань, вилучених на складах у КиєвоПечерській Лаврі. Арх. НБУВ. On. 1. Спр. 72. Арк. 5.

19. Новохатько Л. М. Проблеми соціально-економічного і культурного розвитку України в контексті національної політики (20-30-ті pp. ХХ ст.). Київ : Стилос, $1998.320 \mathrm{c}$.

20. Перечень сведений, составляющих государственную тайну и не подлежащих распространению: Утв. Постановл. Совнаркома РСФСР от $13 / \mathrm{X} / 1921$ г. Х.: И зд. Центр. Упр. по делам печати Главполитпросвета УССР. Тип. Наркомпроса, 1922. 10 с.

21. Очеретянко В. Загратовані книги. Встановлення партійно-державного контролю над виданням, розповсюдженням та використанням літератури в Україні у 20-30-ті роки // 3 арх. ВУЧК, ГПУ, НКВД, КГБ. 1999. № 1/2. С. 128-141.

22. Очеретянко Б. Політична цензура в системі контролю за особистістю та суспільством: До 80-річчя створення рад. цензури // 3 архівів ВУЧК, ГПУ, НКВД, КГБ. 1998. № 1/2 (6/7). С. 70-79.

23. Погребняк В. Репресовані книги. Соџіалістична культура. 1989. № 9. С. 8-9.

24. Постанова РНК від 27 липня 1922 р. «Про організацію Української Книжкової палати УСРР та про забезпечення Головних державних книгосховищ всіма виданнями Республіки». ЦДАВО України. Ф. 2. Оп. 2. Спр. 394. Арк. 41.

25. Постанова 1919 р. НКО РСФРР «Про порядок реєстрації та обліку книг, що видаються в К иєві». ЦДАВО України. Ф. 166. On. 1. Спр. 716. Арк. 24-25 . 
26. Рибалка О. Право свободно мыслить допустимо в известных рамках. Пам’ятки України: історія та культура. 2001. № 1-2 . С. 80-83.

27. Скрынченко Д. Польша и Москва въ отношеніи къ православной вере в Юго-Западной Руси. Киев : Тип. Киево-Печерской Лавры, 1918. С. 1-34.

28. Статут Українського православного Братства імені святих Кирила i Мефодія. Київ : Типографія Києво-Печерської лаври, 1918. 10 с.

29. Тимошик М. Видавнича справа в Україні за радянської доби (1920-1990): орг. аспект. Вісник Книжккової палати. 2004. № 2. С. 40-45.

30. Успенский Н.А. О поруганіи святыхъ мощей [Киево-Печерской Лавры]. Кіевъ, 1919. 15 с.

31. Шикман А.П. «Презумпция разрешённости». Сов. библиография. 1988. № 1. C. 22-31.

32. Федотова О.О. Політична цензура друкованих видань в УСРР-УРСР Ф34 (1917-1990 рр.): Монографія. Київ : Парламентське видавництво, 2009. 352 с.

\section{References:}

1. Antonij (Hrapovickij), mitropolit (1919) Polnoe sobranie sochinenij. T. IV. Kyev: Kievo-Pecherskaja lavra [Complete works]. Kiev: Kievo-Pecherskya Lavra. (in Ukrainian)

2. Asharenkova N.H. (2001) Vplyv tsenzury na diialnist publichnykh bibliotek Ukrainy (20-30 rr. XX st.) [Influence of censorship is on activity of public libraries of Ukraine (20-30 XX of century]. Ukraine of XX of century: culture, ideology, politics, no. 5, pp. 93-101.

3. Bilokin S. (1990) Na polytsyakh spetsfondiv u rizni roky [On the shelves of the specfunds in different years]. Word and time, no. 1, pp. 69-76.

4. Titov F. (1918) Venok na mogilu vysokopreosvjashhennago mitropolita Vladimira [Chaplet on the grave of the most saint metropolitan Vladimir]. Kyiv: Kyjevo-Pechersjka lavra. (in Ukrainian)

5. Bryhynetsъ O., Sopronyuk O. (1990) Lantsyuhova reaktsiya ... porozhnechi [Chain reaction... emptinesses]. Morning, no. 7, pp. 4-6.

6. Gorjaeva T. M. (2002) Politicheskaja cenzura v SSSR 1917-1991 [Political censorship in the USSR 1917-1991]. Moscow: Russian political encyclopaedia. (in Russian)

7. Danylenko V. M., Kas'yanov H. V., Kul'chyts'kyy S. V. (1991) Stalinizm Ukrayini: 20-30-ti roky [Stalinism to Ukraine: 20-30th]. Kyiv: Lybid. (in Ukrainian)

8. Dekret VUTsVK vid 30 kvitnya 1925 r. pro peredannya funktsiy po skladannyu spyskiv zaboronenoyi, konfiskovanoyi abo znyshchenoyi literatury na Ukrayins'ku knyzhkovu palatu (1925). [Decree of the All-Ukrainian Central Executive Committee of April 30, 1925 on the transfer of functions for compiling lists of banned, confiscated or destroyed literature to the Ukrainian Book Chamber] (unpublished).

9. Boykov M. (1919). Dopovid' holovi Tymchasovoho robitnycho-selyans'koho uryadu Ukrayiny X . Rakovs'komu pro stvorennya Narodnoho komisariatu tsenzury USRR (proekt) vid 19 lyutoho 1919 r. [Report to the Chairman of the 
Provisional Workers 'and Peasants' Government of Ukraine X. Rakovsky on the establishment of the People's Commissariat of Censorship of the USSR (draft) of February 19, 1919] (unpublished).

10. Zelenov M. V. (2000). CK VKP(b) - VKP(b), cenzura i istoricheskaja nauka $v$ 1920-e gody [Vehicle of ЦК ВКП (б) - ВКП (б), censorship and historical science in 1920th.]. Nizhniy Novgorod: Nizhpoligraf. (in Russian)

11. Ishchenko V. (1990). Shcho poverneno iz «spetskhraniv» [What is returned from the «special funds»]. Socialistic culture, no 8, pp. 18-19.

12. Isayevych Ya. (1996). Ukrayina davnya i nova: narod, relihiya, kul'tura [Ukraine is old and new: people, religion, culture]. Lviv: Institute of ukrajinoznavstva of the name of I. Kryp'jakevycha. (in Ukrainian)

13. Isayevych Ya. (2002). Ukrayins'ke knyhovydannya: vytoky, rozvytok, problemy [Ukrainian book publishing: origins, development, problems]. Lviv: Institute of Ukrainian Studies of the name of I. Kryp'jakevycha. (in Ukrainian)

14. Kievo-Pecherskaja lavra (1918). Kratkaja letopis’ Pervogo Vseukrainskogo Cerkovnogo sobora i ego vazhnejshie postanovlenija v janvare i ijune 1918 g. [A brief chronicle of the First All-Ukrainian Church Council and its most important resolutions in January and June 1918]. Kyiv: Kievo-Pecherskoy Lavra. (in Ukrainian)

15. Karakoz O. (2004). Bibliotechna tsenzura v Ukrayini v dvadtsyati roky $\mathrm{XX}$ stolittya [Library censorship is in Ukraine in the twentieth of XX of century]. Announcer of book chamber, no. 11, pp. 29-33.

16. Karakoz O. (2003). Vytoky bibliotechnoyi tsenzury na Ukrayini [Sources of library censorship are on Ukraine]. Announcer of book chamber, no. 5, pp. 33-37.

17. Lyst Tsentral'noho bibliohrafichnoho viddilu pry Vseukrayins'komu derzhavnomu vydavnytstvi vid 6 travnya 1922 r. pro peredannya Tsentral'niy knyzhkoviy palati partiyi ukrayins'kykh knyh z metoyu yikh spetsial'noho vykorystannya (1922). [Letter of the Central Bibliographic Department at the All-Ukrainian State Publishing House dated May 6, 1922 on the transfer of a batch of Ukrainian books to the Central Book Chamber for the purpose of their special use] (unpublished).

18. Lyst Komitetu VBU do Politkontrolyu DPU vid 27 lyutoho 1923 r. pro nadannya bibliotetsi odnoho prymirnyka vydan', vyluchenykh na skladakh u Kyyevo-Pechers'kiy Lavri (1923). [Letter of the VBU Committee to the Political Control of the DPU dated February 27, 1923 on providing the library with one copy of the publications seized from the warehouses in the Kiev-Pechersk Lavra] (unpublished).

19. Novokhat'ko L.M. (1998). Problemy sotsial'no-ekonomichnoho $i$ kul 'turnoho rozvytku Ukrayiny v konteksti natsional'noyi polityky (20-30-ti rr. XX st.) [Problems of socio-economic and cultural development of Ukraine in the context of national policy (20-30s of the XX century)]. Kyiv: Stylus. (in Ukrainian)

20. Central'noe Upravlenie po delam pechati Glavnogo politiko-prosvetitel'nogo komiteta USSR (1922). Perechen' svedenij, sostavljajushhih gosudarstvennuju tajnu i ne podlezhashhih rasprostraneniju: Utverzhdennyh Postanovleniem Soveta narodnyh komissarov RSFSR ot 13.10.1921 g. [The list of information constituting a state secret and not subject to distribution: Approved by the decision of the Council of People's Commissars of the RSFSR of 10.13.1921]. Kharkiv: 
Central Press Office of the Main Political Education Committee of the Ukrainian SSR. (in Ukrainian)

21. Ocheretyanko V. (1999). Zahratovani knyhy. Vstanovlennya partiyno-derzhavnoho kontrolyu nad vydannyam, rozpovsyudzhennyam ta vykorystannyam literatury v Ukrayini u 20-30-ti roky [Prisoners books. Establishment of party-state control above edition, distribution and use of literature in Ukraine in 20-30th]. From the archives of VUCHK-GPU-NKVD-KGB, no. 1/2, pp. 128-141.

22. Ocheretyanko V. (1998) Politychna tsenzura v systemi kotrolyu za osobystistyu ta suspil'stvom: Do 80-richchya stvorennya radyans'koyi tsenzury [Political censorship in the system of котролю after personality and society: To the 80 year of creation of soviet censorship]. From the archives of VUCHK-GPU-NKVD-KGB, no. $1 / 2$, pp. $70-79$.

23. Pohrebnyak V. (1989). Represovani knyhy [Subjected to repression books]. Socialistic culture, no. 9, pp. 8-9.

24. Postanova RNK vid 27 lypnya 1922 r. «Pro orhanizatsiyu Ukrayins'koyi Knyzhkovoyi palaty USRR ta pro zabezpechennya Holovnykh derzhavnykh knyhoskhovyshch vsima vydannyamy Respubliky» (1922). [Resolution of the SNC of July 27, 1922 «On the organization of the Ukrainian Book Chamber of the USSR and on the provision of the Main State Bookstores with all publications of the Republic»] (unpublished).

25. Postanova 1919 r. NKO RSFRR «Pro poryadok reyestratsiyi ta obliku knyh, shcho vydayut'sya v Kyyevi» (1919). [Resolution of 1919 of the NGO RSFSR «On the procedure for registration and accounting of books published in Kiev»)] (unpublished).

26. Ribalka O. (2001). Pravo svobodno myslit' dopustimo v izvestnyh ramkah [A right freely to think is possible in well-known scopes]. Sights of Ukraine: history and culture, no. 1-2, pp. 80-83.

27. Skrynchenko D. (1918). Pol'sha i Moskva v otnoshenii k pravoslavnoy vere v Yugo-Zapadnoy Rusi [Poland and Moscow in relation to the Orthodox faith in Southwest Russia]. Kyiv: Kyjevo-Pechersjka lavra. (in Ukrainian)

28. Kyjevo-Pechersjka lavra (1918). Statut Ukrajinsjkogho pravoslavnogho Bratstva imeni svjatykh Kyryla i Mefodija [Statute of the Ukrainian Orthodox Brotherhood named after Saints Cyril and Methodius]. Kyiv: Kyjevo-Pechersjka lavra. (in Ukrainian)

29. Tymoshyk M. (2004). Vydavnycha sprava v Ukrayini za radyans'koyi doby (1920-1990): orhanizatsiynyy aspekt [Publishing business in Ukraine in soviet times (1920-1990): organizational aspect]. Announcer of book chamber, no. 2, pp. $40-45$.

30. Uspenskij N.A. (1919). O poruganii svjatyh moshhej Kievo-Pecherskoj Lavry. [On the desecration of the holy relics Kiev-Pechersk Lavra]. Kiev: KyyevoPechers'ka lavra. (in Ukrainian)

31. Shikman A. C. (1988). Prezumpcija razreshjonnosti [Presumption of settled]. Soviet bibliography, no. 1, pp. 22-31.

32. Fedotova O. O. (2009). Politychna tsenzura drukovanykh vydan' v USRR-URSR (1917-1990 rr.) [Political censorship of printed publications in the USSR-USSR (1917-1990)]. Kyiv: Parliamentary Publishing House. (in Ukrainian) 